\title{
Confusion Concerning the Use of Maqasid Al-Shari'ah in some Social Issues in Malaysia
}

\author{
Muhammad Adib Samsudin \\ Lecturer (PhD) at Department of Shariah, Faculty of Islamic Studies, \\ The National University of Malaysia (UKM) \\ Salasiah Hanin Hamjah \\ Lecturer (Assoc. Professor, PhD) at Department of Dakwah \\ (Preaching) and Leadership, Faculty of Islamic Studies, The National University of Malaysia (UKM)
}

\author{
Doi:10.5901/mjss.2015.v6n6s5p369
}

\begin{abstract}
Social issues relating to the Muslim ummah's permissibility of polygamy for males and obligatory veiling (hijab) for females have become polemic in Malaysia. This polemic is dealt with by using the argument of maqasid al-shari'ah (purposefulness of shariah). However, there is much confusion in presenting the argument of maqasid al-shari'ah whereby the role of reason is given priority over considerations of explicit meaning of the text or evidence in shariah when a social issue is submitted. Hence, this paper explains the confusion in order that any form of resolution to social issues is in accordance with the spirit of al-Quran and Hadith. The method used in this study is document analysis. Among the documents used is, The Relationship Between Islamic Human Rights And The Maqasidic Approach, Muslim Women's Quest for Equality: Between Islamic Law and Feminism, Feminist Movement, Gender Equality and Religious Understanding and Dawabit al-Maslahah fi al-Sharicah al-Islamiyyah (The Guidelines for Public Interest in Islamic Shariah). Research results find that the dawabit (parameters) control the application of maqasid al-shari'ah (the ultimate objectives or goals of Shariah). This is because dawabit plays a role in balancing between proof of Shariah text or evidence in partial (juz'iyy) form and maqasid al-shari'ah in general or universal (kulliyy) form. These dawabit (guidelines) are compiled to ensure that the application of maqasid al-shari'ah fulfils the true discipline of jurisprudence in the context of textual interpretation of al-Quran and al-Sunnah when issuing rulings extracted from these sources.
\end{abstract}

Keywords : Social, Maqasid al-Shari'ah, al-Quran, Hadith

\section{Introduction}

Malaysia has several social issues that have become polemic among the Muslims here. For example, the Joint Action Group for Gender Equality (JAG) (2014) cannot accept it that women would have to cover their hair from the sight of a 'non-Mahram' (marriageable individual). According to JAG, this is against the principles of universal justice; what more if it is associated with Islam, which is formed based on justice. In other words, JAG is of the view that in order to achieve maqasid al-shari'ah (the ultimate objectives or goals of Shariah), freedom should be given to women to abstain from wearing the hijab so that there is fairness between man and woman on the issue of clothing. However, the religious authorities in Malaysia have an opposite view, whereby to wear the hijab is maqasid al-shari'ah and not vice versa. Feminist movements in other places shared the same view held by JAG. For example, Iran and Malaysia were accused of misinterpreting the al-Quran on this issue (Sanam Vakil, 2004), which had caused the failure to achieve maqasid alshari'ah.

Besides that, the issue on polygamy is also fiercely debated. From one aspect, the Sisters in Islam (SIS) are steadfast that Islam only allows a Muslim man to marry one woman at any one time (1993). Marrying more than one woman is considered as deviating from the teachings of Islam (Abdullah et. al, 2015). SIS is of the view that achieving maqasid al-shari'ah in a fair and harmonious marriage is not to practice polygamy. From another aspect, the majority of Muslims, especially the religious authorities, do not forbid the permission for any qualified individual to practice polygamy. This group argues that achieving maqasid al-shari'ah is to practice polygamy with the intention of helping women experience the essence of marriage, especially when the ratio of unmarried women far outweighs men.

Both these issues could be used as examples of polemic in Malaysia that is based on maqasid al-shari'ah. Hence, a guideline on the use of arguments about maqasid (objectives or goals) recognised by syarak should be set up. The guidelines or dawabit for the maqasid is necessary in order to identify the Islamic law according to the al-Quran and 
Hadith. Thus, the study on dawabit maqasid al-shari'ah has not received much attention from researchers in the field of maqasid, although researchers have laid emphasis on the application of maqasid al-shari'ah. For example, Husni, A. B. M., et al., (2015) emphasised the important role of maqasid al-shari'ah in solving problems related to working wives. Omar, A. F., et. Al (2012) and Mohd Nor, A. H., et. Al (2012) applied maqasid al-shari'ah in the formation of national policies. Laluddin, H., et. Al (2012) also applied it to research on human rights. Other researches include its application in the financial and banking sector (Mansour, W, et. Al, 2015, Mansour, W., 2014, Belabes, A. S., 2014, Mohammad, M. O., \& Shahwan, S., 2013) and many more.

Hence, by looking at the early history of maqasid al-shari'ah, al-Shatibiyy, as among the figures that pioneered the debate on maqasid al-shari'ah, had not elaborated further about dawabit, although it is necessary when ensuring that the rulings (hukum) based on maqasid al-shari'ah do not contradict the al-Quran and Hadith. This is because the maqasid alshari'ah is only ma'na kulliyy (complete induction), which is the summary of a collection of rulings (hukum) in the form of juz'iyy (partial rulings) that is based on tafsiliyy (in detail or comprehensive form). Therefore, maqasid must be monitored to ensure a balance between the objective that is based on kulliyy and the religious references for the rulings (dalil hukum) that are based on tafsiliyy. When the balance has been achieved between the kulliyy and tafsiliyy, the contradicting issues between maqasid al-shari'ah and the other religious references (dali) from the syarak would not arise. This is because the dawabit acts by exposing the meaning of kulliyy and at the same time becomes a binding force for the religious references (dalii) related to the rulings that are in the form of tafsiliyy.

\section{Dawabit Al-Maslahah in the Context of Discussing Maqasid Al-Shari'ah}

The relationship between al-maslahah and maqasid al-shari'ah is clearly seen in the definitions of both these terms. The definition for maqasid al-shari'ah is "an objective determined by Islamic syariat and achieved in the interest of human beings" (al-Raisuniyy, t.th). The objective covers several elements such as daruriyyah, hajiyah and tahsiniyyah (alShatibiyy, t.th), which contains five basic elements such as religion, the soul, the mind, family lineage and property (alButiyy, 2010). Whereas, the definition of al-maslahah according to scholars on figh is summarised ${ }^{1}$ as "benefits referred to by Allah SWT, The Most Wise, for his subjects who preserve and nurture their faith, soul, mind, family lineage and property" (al-Butiyy, 2010). ${ }^{2}$

Based on both the definitions above the common factor between both the definitions is the preservation and nurturing of faith, soul, mind, family lineage and property, which is found in three segments such as al-daruriyyat, alhajiyyat and al-tahsiniyyat. Therefore, maqasid al-shari'ah and maslahah are actually two faces of the same coin. Hence, indirectly dawabit for maslahah is similar to dawabit for maqasid al-shari'ah. Thus, elaborations about dawabit almaslahah are important, especially when discussing maqasid al-shari'ah as an instrument for formulating rules (hukum) on syarak based on references from the Al-Quran and Hadith.

\section{Dawabit Al-Maslahah Al-Shar'iyyah}

Dawabit is the plural for dabit, which means "to protect or preserve (al-Raziyy, 1992) something from mixing with something else" (al-Butiyy, 2010). Maslahah needs to be protected by dawabit because maslahah is not a religious reference by itself, such as the al-Quran, al-Sunnah, ijmak or qiyas but it is only macna kulliyy. This means that maslahah is formed based on the conclusions made after compiling the rulings (hukum) in the form of juz'iyy, which relies on religious references that are tafsiliyy (al-Butiyy, 2010)3. Hence, maslahah (benefits) must be nurtured and controlled so that there is a balance between its meaning according to kulliyy and the rulings (hukum) based on the religious references (dalil atau nas)that are tafsiliyy. In other words, the benefits (kemaslahatan) accrued via cognizance and observation of the rulings (hukum) in the syarak in the form of juz'iyy is congruent and does not contradict the religious references (nas) in the syarak

Therefore, when considering the benefits (maslahah) according to Islamic legislation, from one aspect, it must be subjected to guidelines (dawabit) that act to restrict its meaning according to kulliyy and from another aspect; it must be reconciled with religious references on tafsiliyy pertaining to rulings on syarak until there is compatibility between kulliyy and juz'iyy.

\footnotetext{
1 This is because there are numerous definitions given although the topic of discussion is the same.

2 This is the result of the conclusion made by al-Butiyy based on the definitions by al-Ghazali and al-Razi.

${ }^{3}$ After istiqra' is initiated towards all the religious references in the syarak, either the al-Quran or Hadith, thus it was found that it was intended to safeguard the maslahah and reject the mafsadah.
} 
Hence, there would be a contradiction between the maslahah (maqasid al-shari'ah) and other religious references from the syarak because the existence of guidelines (dawabit) act as an introduction to a meaning that is kulliyy and at the same time become a binding force to the religious references (dali) used in the rulings (hukum) in the tafsiliyy form. Thus, if there exist some contradiction between maslahah and the religious references in the tafsiliyy form, then the contradiction could be either between a false maslahah or between a maslahah that relies on religious references in the juz'iyy, which could be reconciled according to methods found in the principles of Islamic jurisprudence (Usul al-Fiqh). The guidelines (dawabit) are divided into five sections, namely maslahah, which is a part of maqasid al-Sharic, maslahah that does not contradict the al-Quran, maslahah that does not contradict the Hadith, maslahah that does not contradict the qiyas or neglect a maslahah that is as important as or more important than it is.

\title{
3.1 Maslahah that is a part of maqasid al-Shari'4
}

Maqasid al-Shari' is intended to safeguard the benefits (kemaslahatan) and global human well-being. It is divided into five elements such as religion, the soul, the mind, family lineage and property. These five elements are further grouped into three groups according to their significance, such as al-daruriyyat, al-hajiyat and al-tahsiniyyat. The core matter among the five maqasid above is the platform for realising one objective only, which is all Muslims who are mukallaf (come of age) are subjects of Allah SWT. Therefore, actions of the mukallaf that contradict the meanings of the syarak are presumed irrelevant to the maslahah that are accepted by syarak (al-Butiyy, 2010).

\subsection{Maslahah that does not contradict the al-Quran}

The second guideline (dabit) states that the maslahah should not contradict the rulings extracted from the religious references (nas) quoted from the al-Quran. One such religious reference is the exhortation by Allah SWT meaning,

\begin{abstract}
"And judge, [O Muhammad], between them by what Allah has revealed and do not follow their inclinations and beware of them, lest they tempt you away from some of what Allah has revealed to you. And if they turn away - then know that Allah only intends to afflict them with some of their [own] sins. And indeed, many among the people are defiantly disobedient." (Al-Maidah, 5:49)
\end{abstract}

This verse clearly indicates that Allah SWT commanded that every verse delivered by HIM should become the main reference. References that do not rely on Allah SWT in reality do no refer to religious references but follow human impulses. Hence, the ruling (hukum) for solving any discord that arises is to refer to religious references (nas) from the alQuran or Hadith.

Hence, if there are contradictions between maslahah and the al-Quran, then what could occur is an encounter between maslahah mawhumah ${ }^{5}$ and religious references from the al-Quran, either in the form of qat'iyy, zahir, jaliyyy or ghayr jaliyy. Conversely, if maslahah is a branch of the original religious reference that is coalesced with 'illah qiyasiyyah; hence, this contradiction in reality is a contradiction between two religious references that occur as juz'iyy, such as alkhas and al-'am or al-mutlaq and al-muqayyad. At that instance, ijtihad (independent reasoning) is permitted, either to perform takwil (exegesis) or tarijh (elimination by comparison) in order to determine the position of being benevolent (amal) with the masalah and religious references (al-Butiyy, 2010).

\subsection{Maslahah that does not contradict the Hadith}

Besides the al-Quran, maslahah cannot contradict religious references in the Hadith that clarify a ruling (hukum). The verse in Surah al-Ma'idah mentioned above is enough to prove the third dabit. In addition, Allah SWT had exhorted:

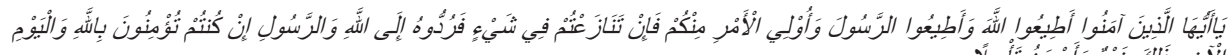

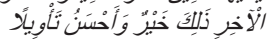

\footnotetext{
${ }^{4}$ There could be some confusion about the first dabit, considering the maslahah itself could be maqasid al-Sharic and at the same time, it is monitored by maqasid. However, this confusion is settled easily because maqasid acts as an introduction to the meaning of kulliyy for maslahah. In other words, a particular matter could be maslahah if it intends to adress five basic issues, namely religion, the soul, the mind, family lineage and property, which happens to be maqasid al-Sharic or al-sharicah. Whereas, the remainding four dawabit almaslahah act to bind the maslahah and the religious references (dalil) for the ruling (hukum) that are in the form of tafsili.

${ }^{5}$ Maslahah that does not rely on religious references from the al-Quran or al-Sunnah.
} 
"O you who have believed, obey Allah and obey the Messenger and those in authority among you. And if you disagree over anything, refer it to Allah and the Messenger, if you should believe in Allah and the Last Day. That is the best [way] and best in result." (Al-Nisa, 4:59)

The religious references above clearly show that any discord must be referred to the al-Quran or Hadith. Hence, each ruling (hukum) that refers to the maslahah cannot contradict the Prophet's SAW Hadith. If there is a contradiction, possibly the mashalah is only a presumption or the contradiction is in the form of juz'iyy, which could be resolved using methods found in the principles of Fiqh, as stated in the second dabit.

\subsection{Maslahah that does not contradict the al-qiyas}

The fourth dabit is maqasid al-shari'ah or maslahah that does not contradict the al-qiyas. This is because al-qiyas functions to safeguard maslahah so that it remains at the same branch (furuk) or category as maslahah mutlaqah or maslahah mursalah. Thus, the ratio between al-qiyas and maslahah mutlaqah is general and specific because al-qiyas addresses maslahah, in fact with an addition, namely the cillah in the al-qiyas. The situation is different when solely addressing the maslahah because it is more general in nature due to maslahah mursalah. Hence, maslahah must be monitored by al-qiyas because every al-qiyas would surely address the maslahah but not vice-versa (al-Butiyy, 2010).

Besides that, it would be difficult for the maslahah to contradict the al-qiyas because of the cillah, which is one of the rulings (hukum) in al-qiyas. This is because the strength of the suitable character (wasf al-munasib) that causes the existence of this ruling (hukum) differs, such as ${ }^{6}$ mu'aththir, mula'im, gharib and mursal (al-Taftazaniyy, 1317H). This differentiation is an important guide for setting the decorum and order pertaining to the position of the characteristics that should be considered if there is a contradiction (ta'arud) during efforts to identify and substantiate the rulings (hukum) from syarak (al-Butiyy, 2010).

\subsection{Maslahah that does not neglect a more important maslahah or one of similar importance}

The final dabit involves a maslahah that does not neglect a maslahah that is more important or of similar importance. This is because the maslahah's order of priority, although not consistent, differs in importance. This is viewed from three aspects, namely from the essence of the maslahah, its scope or assurance of the desired outcome. The first aspect is divided into three levels according to the decorum that must be given priority if there are any contradictions, namely maslahah daruriyyah, maslahah hajiyyah and maslahah tahsiniyyah. If the contradiction occurs at the same level, then it would be evaluated according to its scope whether the maslahah is 'ammah (general) or khassah (specific), with the maslahah 'ammah given priority compared to maslahah khassah. The most important and basic aspect is the presumption that the maslahah would materialise (rujhan al-wuqu') in reality and is evaluated to determine whether it belongs to the category of daruriyyah, hajiyyah, 'ammah (al-Butiyy, 2010).

\section{Conclusion}

After elaborating on dawabit or the guideline for maqasid al-shari'ahi; hence, the polemic of the two issues raised earlier in the study, which is the issue of the need for women to cover their aurat and the issue of polygamy, could be resolved easily. This is because both these issues have religious references (nas) found in the al-Quran and Hadith. Among the religious references (nas) from the al-Quran related to the covering of the aurat is found in verse 59 Surah Al-Ahzab.

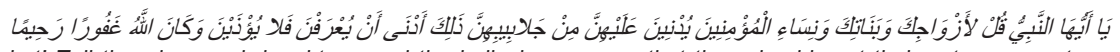

"O Prophet! Tell thy wives and daughters, and the believing women, that they should cast their outer garments over their persons (when abroad): that is most convenient, that they should be known (as such) and not molested. And Allah is Oft-Forgiving, Most Merciful"

The religious reference above shows that Allah SWT had commanded pious women to cover their aurat. Thus, maqasid al-shari'ah in this issue is that the aurat should be covered and not exposed because maqasid al-shari'ah cannot contradict the religious references found in the al-Quran. Meanwhile, a religious reference (nas) from the Hadith mentioned:

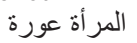

${ }^{6}$ According to a decending order (from the strongest to the weakest). 
Meaning: Women (in themselves) are the aurat.

The religious reference from the Hadith narrated by al-Tirmizi clearly shows that the woman's body is the aurat. Hence, it must be covered. Based on the second dabit, the maqasid al-shari'ah cannot contradict the religious reference (nas) from the Hadith.

This is similar to the issue of polygamy, in which a verse from the al-Quran explicitly allows men to practice polygamy. Allah SWT exhorted (al-Quran, 4:3)

"If ye fear that ye shall not be able to deal justly with the orphans, Marry women of your choice, Two or three or four; but if ye fear that ye shall not be able to deal justly (with them), then only one, or (a captive) that your right hands possess, that will be more suitable, to prevent you from doing injustice"

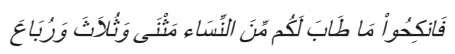

The religious reference above binds the maqasid al-shari'ah by stating that men are permitted, according to certain conditions, to practice polygamy, and not the opposite.

Hence, the debate on guidelines (dawabit) for maqasid al-shari'ah is important because it is related to identifying rulings (hukum) based on the syarak. This understanding can be confusing especially if it is intentionally staged by enemies of Islam who wish to attack the perceptions held by Muslims. The attacks are usually through the mode of ijtihad and al-ra'y (views) by using false maslahah. Pertaining to this matter, Dr. Muhammad Said Ramadan al-Butiyy (2010) said:

"This is a new round started by the enemies of Islam in their efforts to wage war with Islam. Thus, with a responsibility shouldered by Muslims today to arrest this attack and create awareness about it, I have been thinking for some time now to initiate a study on Dawabit al-Maslahah fi al-Shar'cah al-Islamiyyah."

The above statement clearly shows that the original intention to formulate the dawabit maslahah was to safeguard the method of deducing religious references based on the syarak from being disrupted by irresponsible parties who wish to destroy Islam. This is concrete proof that jihadist scholars of Ahl al-Sunnah wa al-Jama'ah are steadfast in ensuring the use of the original principles of Figh in the context of interpreting religious references from the al-Qur'an and alSunnah. ljtihad, or more specifically ijtihad al-maqasidi, should be approached with caution and care since it is subject to methods and disciplines mentioned in the al-Qur'an and al-Sunnah that should be adhered to in order to avoid being misled. Dr. al-Butiyy (2010) again explained:

"Every time I read or hear a call for ijtihad at the present time by considering the maslahah as a benchmark for understanding the syariah, I feel the over-compelling question within me that asks, "what is the dawabit al-maslahah that is frequently talked about?" If to ijtihad is considered compulsory for the ulama, even once, is it compulsory for them a thousand times over to endeavour tirelessly to understand the reality of maslahah shar'iyyah, its limitations, its dawabit or even its foundations?"

Pertaining to the truth of this ijtihad, al-Shaykh Dr. 'Abd. al-Halim Mahmud rahimahuLlah stated:7

"The actual meaning of ijtihad is to effortlessly and continuously try to obey and adhere to every action and deed carried out by the Prophet SAW and to subject all new problems to the ancient methods summarised from the exhortation of the Prophet SAW and the al-Quran. ljtihad has no other meaning other than this" ('Abd al-Halim Mahmud, t.th).

The statement above shows that the practice of depicting rulings (hukum) from the syarak is subject to manhaj (methodology of receiving, analyzing and applying knowledge) that existed then, ever since Prophet Muhammad SAW ${ }^{8}$ delivered it. Manhaj is a guide for understanding and interpreting the religious references (nas) found in the al-Quran and

\footnotetext{
${ }^{7} \mathrm{He}$ (rahimahullah) was the former Shaykh al-Azhar (the highest position in al-Azhar al-Sharif). He was born in Egypt, in a village called al-Salam, located in the Sharqiyyah area on $10 \mathrm{Mei}$ 1910. He had attended innumerable conferences on Islam in and outside the country. He was a visiting professor at several universities in Tunis, Libya and the Philippines. His literary work covered various fields such as tasawwuf, philosophy, figh etc. consisting of more than 64 books. The titles of his works were al-Islam wa al-Iman, al-clbadat, alTacrif al-Falsafi fi al-Islam and al-Islam wa al-cAql. He died on 17 October 1978.

${ }^{8}$ Manhaj, pertaining to either the principles or the practice of Islamic academic knowledge, have existed from the times of the Prophet SAW and HIS companions but the study, research and writings as well as the editorial work on manhaj only emerged halfway through the salaf al-salih.
} 
al-Sunnah when summarising the rulings (hukum) of the syarak and guiding the thinking process or ijtihad. This manhaj ${ }^{9}$ has become a principle held by the entire generation of Muslims since the existence of Islam in their efforts to understand the al-Quran and al-Sunnah. Therefore, Muslims who are committed to the al-Quran and al-Sunnah possess a permanent measure for interpreting religious references. At the same time, manhaj acts to guide, bind and ensure that the actual and authentic views or ijtihad adhere to the potent religious references.

\section{Acknowlegdement}

The author(s) disclosed the receipt of the following financial support for the research, authorship, and/or publication of this article: Part of the research carried out for this article is made possible through the project entitled, "Application of Maqasid Shariah in the Lifestyle of a Muslim Professional to Build a Spiritual Well-being (AP-2014-020)" and "An Exploratory Research on the Establishment of Shari'ah Supervisory Committee In Hospital (ERGS/1/2013/SSI03/UKM/02/1)"

\section{References}

Al-Quran.

'Ulwan, F.M. (1989). al-Qiyam al-daruriyyah wa maqasid al-tashric al-Islami. Mesir : al-Hai'at al-Misriyyat al-'Ammah li al-Kitab.

Abdullah, R.a, Abdullah, S.b , Ferdousi, N.c. (2015). The fragile status of a Muslim wife: The legal history of polygamy in Malaysia. Journal of Family History. 40 (2), 135-152.

Belabes, A. S. (2014). Maqasid dimensions of finance in a complex world: Methodological comparison between islamic and conventional economic literature. Journal of King Abdulaziz University, Islamic Economics, 27(3), 45-96.

Al-Butiyy, M.S.R. (1421H/2000). Dawabit al-maslahah fi al-shari'ah al-Islamiyyah. Cet. ke-6. Beirut : Mu'assasat al-Risalah.

Husni, A. B. M., Nasohah, Z., Nor, A. H. M., \& Samuri, M. A. (2015). Family problems - Wife's work - and its solution in the light of maqasid shariah. Asian Social Science, 11(18), 164-173.

Joint Action Group for Gender Equality. (2014, January). A woman's right to choose her clothing. Retrieved July 13, 2015, from http://www.sistersinislam.org.my/news.php?item.1251.120.

Laluddin, H., Mohd. Nor, A. H., El-Seoudi, A. W. M. M., Ibrahim, I. A., Husni, A. M., Omar, A. F., Samsudin, M.A., Alias, M.N., Mohamad, A. B. B. (2012). The relationship between islamic human rights and the maqasidic approach. Social Sciences, 7(1), 111-116.

Mahmud, A.H. (t.th). al-Islam wa al-caql. Cet. ke-4. al-Qahirah : Dar al-Ma'arif.

Mansour, W, Ben Jedidia, K, Majdoub, J. (2015). How ethical is islamic banking in the light of the objectives of islamic law?.Journal Of Religious Ethics, 43 (1), 51-77.

Mansour, W. (2014). Maqasid foundations of market economics. Journal of Islamic Studies, 25(3), 400-402.

Mohammad, M. O., \& Shahwan, S. (2013). The objective of islamic economic and islamic banking in light of maqasid al-shariah: A critical review. Middle East Journal of Scientific Research, 13(SPLISSUE), 75-84.

Mohd Nor, A. H., Alias, M. N., Samsudin, M. A., Omar, A. F., Ibrahim, I. A., Laluddin, H., Manap, N. A. (2012). Application of the principles of maqasid shari'ah in administration of the islamic countries. Advances in Natural and Applied Sciences, 6(6), 847851.

Omar, A. F., Mohd Nor, A. H., Alias, M. N., Samsudin, M. A., Ibrahim, I. A., Laluddin, H., Husni, A. M. (2012) The importance of the maqasid al-shari'ah in the process of governing and policy making. Advances in Natural and Applied Sciences, 6(6), 823-830.

Al-Raisuniyy, A. (t.th). Nazariyyat al-maqasid cinda al-Imam al-Shatibiyy. t.tp : al-Machad li al-Fikr al-Islami.

Al-Raziyy, F.M. (1408H/1988). al-Mahsul fi cilm al-usul. 2 Jil. Beirut : Dar al-Kutub al-cllmiyyah.

Al-Raziyy, M.A. (1407/1992). Mukhtar al-sihhah. Cet. ulang. Beirut : Maktabah Lubnan.

Rosadi, A. (2011). Feminisme Islam: Kontekstualisasi prinsip-prinsip ajaran Islam dalam relasi gender. 1(1).

Sanam, V. (2004). Islamic Fundamentalism, Feminism, and Gender Inequality in Iran under Khomeini by Masoud Kazemzadeh. International Journal of Middle East Studies, 36 (1), 137-138.

Al-Shatibiyy, I. (t.th). al-Muwafaqat fi usul al-sharicah sunt. cAbdullah Darraz. 2 jil. Beirut : Dar al-Kutub al-cllmiyyah.

Sisters In Islam. (1993). Islam and polygamy. Retrieved July 13, 2015, from http://www.sistersinislam.org.my/news.php?item.291.7

Al-Taftazaniyy, S. (1317H). Hashiyat al-callamah Sacd al-Din al-Taftazaniyy. 2 jil. Bulaq : Matbacah al-Kubra al-Amiriyyah

Al-'Ubaidiyy, H. (1413H/1992). al-Shatibiyy wa maqasid al-shari'ah. Beirut : Dar Qutaibah.

\footnotetext{
${ }_{9}^{9}$ Manhaj here does not mean a technique or a system of studying academic knowledge but a path (al-tariqah) that would lead a researcher towards the truth, either in the form of news that should be authenticated or an issue whose evidence that needs to be authenticated and verified.
} 